B. Gürdal, S. Demirci, N. Özhatay \& E. Kaya

\title{
Chromosome numbers of 9 taxa of Lilium (Liliaceae) from Turkey
}

\begin{abstract}
Gürdal, B., Demirci, S., Özhatay, N. \& Kaya, E. 2016: Chromosome numbers of 9 taxa of Lilium (Liliaceae) from Turkey [In Kamari, G., Blanché, C. \& SiljakYakovlev, S. (eds), Mediterranean plant karyological data - 26]. - Fl. Medit. 26: 220223. doi: 10.7320/FlMedit26.220

In the present study the chromosome number of 9 Lilium taxa from Tukish populations is given. For three of them the somatic number is given for the first time. Additionally, the presence of B chromosomes has been observed for Lilium kesselringianum, Lilium ponticum var. artvinense and Lilium szovitsianum, while a new chromosome number for Lilium candidum is reported.
\end{abstract}

\section{Introduction}

This report is based on the specimens collected during the Geophyte Project (110G007), carried out in the Atatürk Horticultural Central Research Institute (Yalova). Plant specimens were collected from nature and planted in the geophytes research garden in Yalova. Actively growing root tips used for the chromosome counts were collected from the garden. The methods followed standard chromosome counting procedure in ISTE (Koçyiğit $\&$ Bona 2013). As a result, chromosome number of 9 taxa are counted, 3 of them are reported for the first time in this study.

1872. Lilium akkusianum R. Gämperle $-2 n=24+0-1 \mathrm{~B}$.

Tu: Tokat; Erbaa, Madenli Köyü, Armudun altı mevkii, 1147 m, 15 Apr 2008 (Hort. coll. no: L6001).

- Tokat; Erbaa, Gökal Köyü, Çermik Mahallesi, orman açıklıkları, 1358 m, 02 Jul 2008 (ISTE 93709).

Lilium akkussianum is an endemic species described from N Anatolia (Gamperle 1998). The chromosome number is reported for the first time.

1873. Lilium armenum Grossh. $-2 n=24$.

Tu: Ardahan; Damaldan Arap Mezarlarına, Üçdere ağaçlandırma, 1800-1900 m, 15 Jul 2009 (Hort. coll. no: L7506). 
Lilium armenum was reported as $2 n=24$ in the literature (Kudriashova 1969). Our result is in accordance to the previous study.

1874. Lilium candidum L. $-2 n=24,32$.

Tu: Muğla; Marmaris, İçmeler-Bayırköy yolu, İçmeler üstü, 241 m, 14 Mar 2008 (Hort. coll. no: L4805).

The somatic number of Lilium candidum $2 n=24$ has been previously reported (Smyth $\&$ al. 1989; Agnieszka \& al. 2005). In the present study $2 n=24$, as well as $2 n=32$ chromosomes are counted.

1875. Lilium ciliatum P.H. Davis $-2 n=24$.

Tu: Trabzon; Maçka, Bekçiler Köyü civarı eski yol üzeri, 1657 m, 13 Jul 2007 (Hort. coll. no: L6107).

Lilium ciliatum is an endemic species from Turkey. The chromosome number reported here, $2 n=24$, is in accordance with a previous report (Özdemir 2003).

1876. Lilium kesselringianum Miscz. $-2 n=24+0-2 \mathrm{~B}$

Tu: Artvin; Sahara, Yalnızçam dağı, Şavşat, 2185 m, 12 Sept 2006 (Hort. coll. no: L0801).

In the literature, the chromosome number of Lilium kesselringianum is reported as $2 n=$ 24 (Kudriashova 1969; Zakharyeva \& Makushenko 1969). In this study, the somatic number is the same, while $0-2 \mathrm{~B}$ chromosomes are observed.

1877. Lilium martagon L. $-2 n=24$.

Tu: İstanbul; Belgrat Ormanları, Atatürk Arboretumu, 100 m, 05 Jun 2005 (Hort. coll. no: L3401).

The chromosome number of $2 n=24+0-2 \mathrm{~B}$ for Lilium martagon is also reported in the literature (Holub \& al. 1972; Murin \& al. 1980; Strid \& Franzen 1981; Malakhova \& Markova 1994).

1878. Lilium ponticum K. Koch $-2 n=24$.

Tu: Trabzon; Çaykara, Karaçamdan Soğanlıya çıkış yolu, 1959 m, 15 Apr 2006 (Hort. coll. no: L6101). 
The chromosome number of Lilium ponticum is reported for the first time in this study.

1879. Lilium ponticum var. artvinense (Miscz.) P.H. Davis \& D.M. Hend. $-2 n=24+0-3 \mathrm{~B}$.

Tu: Artvin; Kafkasordan-Madene giderken yol üzeri, 1701 m, 13 Apr 2006 (Hort. coll. no: L0803).

The chromosome number reported here is counted for the first time and B chromosomes are observed.

1880. Lilium szovitsianum Fisch. \& Avé-Lall. $-2 n=24+0-1 \mathrm{~B}$.

Tu: Ardahan; Çıldır, Kenarbel Köyü, Aktaş Gölü, Ercan mevkii, 1975 m, 30 Aug 2007 (Hort. coll. no: L7505).

The chromosome number $2 n=24$ for Lilium szovitsianum has already been given (Kudriashova 1969). In this study, we observed the presence of a B chromosome in some metaphase plates.

\section{References}

Agnieszka, M., Śliwińska, E. \& Orlikowska, T. 2005: Cytogenetic analysis of eight lily genotypes. - Caryologia 58(4): 359-366. doi: 10.1080/00087114.2005.10589474

Gamperle, R. 1998: A new species of lily from Turkey. - Quart. Bull. Alp. Gard. Soc. 66(3): 378-389.

Holub, J., Měsíček, J. \& Javůrková, V. 1972: Annotated Chromosome Counts of Czechoslovak Plants (31-60). - Folia Geobot. Phytotax. 7(2): 167-202.

Koçyiğit, M. \& Bona, M. 2013: Chromosome Numbers of Five Turkish Centaurea L. (Asteraceae) Species. - Pl. Biosyst. 147: 970-978. doi: 10.1080/11263504.2013.789454

Kudriashova, G. L. 1969: A comparative-karyological investigation of Caucasian Lilies. - Bot. Žurn. (Moscow \& Leningrad) 54: 1074-1082.

Malakhova, L. A. \& Markova, G. A. 1994: Chromosome numbers in the flowering plants of Tomsk region. Monocotyledones. - Bot. Žhurn. (Moscow \& Leningrad) 79(7): 134-135.

Murin, A., Haberova, I. \& Zamsran, C. 1980: Karyological studies of some species of the Mongolian flora. - Folia Geobot. Phytotax. 15: 395-405.

Özdemir, C. 2003: Morphological, anatomical and cytological characteristics of endemic Lilium ciliatum P. H. Davis (Liliaceae) in Turkey. - Pakistan J. Bot. 35(1): 99-110.

Smyth, D. R., Kongsuwan, K. \& Wisudharomn, S. 1989: A survey of C-band patterns of Lilium (Liliaceae). - Pl. Syst. Evol. 163: 53-69.

Strid, A. \& Franzen, R. 1981: Reports. [In Löve, Å. (ed.), Chromosome number reports LXXIII]. - Taxon 30: 829-842. 
Zakharyeva, O. I. \& Makushenko, L. M. 1969: Chromosome numbers of monocotyledons belonging to the families Liliaceae, Iridaceae, Amaryllidaceae, Araceae. - Bot. Žurn. (Moscow \& Leningrad) 54: 1213-1227.

Addresses of the authors:

Bahar Gürdal $^{1}$, Serpil Demirci ${ }^{2}$, Neriman Özhatay ${ }^{1} \&$ Erdal Kaya $^{3}$,

${ }^{1}$ Department of Pharmaceutical Botany, Faculty of Pharmacy, İstanbul University, 34116, Fatih/İstanbul, Turkey. E-mail: bahar_ps@yahoo.com

${ }^{2}$ Department of Pharmaceutical Botany, Faculty of Pharmacy, Çukurova University, 01330, Adana, Turkey.

${ }^{3}$ Ornamental Plants Department, Atatürk Horticultural Central Research Institute, 77102, Yalova, Turkey. 